\title{
PHYSICAL ACTIVI
}

What is the effect of a fast food vers
response to an exercise challenge?

Silva, Diana; Moreira, Rita; Beltrão, Marília; Sokhatska, Oksana;

Autor(es): $\quad$ Montanha, Tiago; Pizarro, Andreia; Pinto, Mariana; Garcia-Larsen, Vanessa; Villegas, Rodrigo; Delgado, Luís; Moreira, Pedro; Carvalho, Joana; Moreira, André

Publicado por: Imprensa da Universidade de Coimbra

URL persistente:

URI:http://hdl.handle.net/10316.2/44148

DOI:

DOI:https://doi.org/10.14195/2182-7087_ex2018_85

Accessed : $\quad$ 26-Apr-2023 13:54:59

A navegação consulta e descarregamento dos títulos inseridos nas Bibliotecas Digitais UC Digitalis, UC Pombalina e UC Impactum, pressupõem a aceitação plena e sem reservas dos Termos e Condições de Uso destas Bibliotecas Digitais, disponíveis em https://digitalis.uc.pt/pt-pt/termos.

Conforme exposto nos referidos Termos e Condições de Uso, o descarregamento de títulos de acesso restrito requer uma licença válida de autorização devendo o utilizador aceder ao(s) documento(s) a partir de um endereço de IP da instituição detentora da supramencionada licença.

Ao utilizador é apenas permitido o descarregamento para uso pessoal, pelo que o emprego do(s) título(s) descarregado(s) para outro fim, designadamente comercial, carece de autorização do respetivo autor ou editor da obra.

Na medida em que todas as obras da UC Digitalis se encontram protegidas pelo Código do Direito de Autor e Direitos Conexos e demais legislação aplicável, toda a cópia, parcial ou total, deste documento, nos casos em que é legalmente admitida, deverá conter ou fazer-se acompanhar por este aviso. 


\section{ANNALS OF RESEARCH IN SPORT AND PHYSICAL ACTIVITY}




\title{
WHAT IS THE EFFECT OF A FAST FOOD VERSUS A MEDITERRANEAN MEAL IN THE ADIPOKINE RESPONSE TO AN EXERCISE CHALLENGE?
}

\begin{abstract}
Diana Silva; Rita Moreira²; Marília Beltrão3; Oksana Sokhatska3; Tiago Montanha4; Andreia Pizarro4; Mariana Pinto3; Vanessa Garcia-Larsen"; Rodrigo Villegas; Luís Delgado; Pedro Moreira²; Joana Carvalho4; André Moreira'
\end{abstract}

\section{BACKGROUND}

Adipose tissue-derived adipokines are pro-inflammatory cytokines thought be involved in metabolic-related diseases. Obesity and poor diet can affect levels of adipokines. Acute exercise challenge can also influence the adipokine, myokine and adipo-myokine response. We aimed to compare the effect of a Mediterranean (MdM) vs. fast food meal (FFM) on the response of adipokines to an acute exercise challenge.

\section{METHODS}

In a double blinded cross over trial, 46 participants were randomly assigned to eating one of two standardized iso-energetic meals: a FFM including a burger, French fries and Cola or a MdM, comprised of vegetable soup, pasta, tomato, olive oil, herbs, garlic, bread, sardines, fruit and water. Three hours after eating the meal, participants completed a tread-

\footnotetext{
1 Basic and Clinical Immunology, Department of Pathology, Faculty of Medicine, University of Porto, Porto, Portugal; Serviço de Imunoalergologia, Centro Hospitalar de São João E.P.E., Porto, Portugal.

2 Faculty of Nutrition and Food Sciences, University of Porto, Porto, Portugal.

${ }^{3}$ Basic and Clinical Immunology, Department of Pathology, Faculty of Medicine, University of Porto, Porto, Portugal.

${ }^{4}$ Research Centre in Physical Activity, Health and Leisure - Faculty of Sports, Porto, Portugal.

${ }_{5}^{5}$ Respiratory Epidemiology, Occupational Medicine, and Public Health Group, National Heart and Lung Institute, Imperial College London, United Kingdom.

${ }^{6}$ School of Public Health, University of Chile, Independencia 939, Santiago, Chile.

Email: disolha@gmail.com
} 
mill exercise test (EC). After a seven day wash out period, the intervention was repeated with the opposite meal. Blood samples were obtained before and after each meal, and immediately after the EC. Demographic, anthropometric characteristics, moderate-to-vigorous physical activity, dietary intake during wash out period and serum cortisol were assessed and included as potential confounders. Blood level of adipokines were determined by a Luminex magnetic bead immunoassay, with a human adipokine panel (HADK1MAG-61K, EMD Miillipore $\left.{ }^{8}\right)$ that included Adiponectin, Resistin, PAI-1, Lipocalin-2/NGAL and Adipsin. Wilcoxon signed rank test applied to compare changes before/after meal and before/after EC. A linear mixed model (LMM) was used to evaluate the effect of meals on the adipokine response to exercise.

\section{RESULTS}

Thirty-nine participants (mean age 25 years) completed the trial (56\% females). There were no differences in oxygen consumption, carbon dioxide production or respiratory exchange ratio during EC. The post EC heart rate was higher in the group who ate the FFM $(p=0.001)$. In both intervention arms there was a statistically significant reduction of adipsin after each meal (Variation MdM -234.3(-1099.8;197.7); Variatin FFM -304.5(-623.7;-100.42), with no difference between groups $\mathrm{p}=0.936)$. After the $E C$, adipsin, lipocalin, PAI-1 and resistin, significantly increased in both intervention groups. Results did not differ between meals. Using a LMM, adjusted for confounders, when EC was preceded by a MdM there was a higher increase in adipsin serum levels. PAI-1 and resistin results were similar after adjusting for potential confounders.

\section{CONCLUSION}

A pre-exercise Mediterranean meal potentiates the increase of adipsin after treadmill exercise test, which possibly relates to the immune regulatory role of adipsin; nevertheless, an increase in adipsin levels has recently been correlated with an improvement of â cell function. Adipsin, PAI-1 and resistin increased after an exercise challenge. This response might vary accordingly to the type and intensity of exercise, therefore should be considered when assessing the adipokine responses to acute or long term exercise interventions. 